The Buckingham Journal of Language and Linguistics 2015 Volume 8 pp 56-78

\title{
A STUDY OF COHESION IN INTERNATIONAL POSTGRADUATE BUSINESS STUDENTS' MULTIMODAL WRITTEN TEXTS: AN SF-MDA OF A KEY TOPIC IN FINANCE
}

\author{
Hesham Suleiman Alyousef \\ King Saud University \\ Saudi Arabia \\ hesham@ksu.edu.sa
}

\author{
Suliman Mohammed Alnasser \\ King Saud University \\ Saudi Arabia \\ smalnasser@ksu.edu.sa
}

\begin{abstract}
Empirical research studies of finance students' language use have investigated students' performance in finance courses and the effect of class attendance on students' performance. Similarly, research on accounting students' texts has been directed at readability of accounting narratives and lexical choices. Systemic Functional Linguistics (SFL) based research in multimodal communication and representation has been confined to school and workplace contexts. Whereas multimodal communication investigations in tertiary contexts has been conducted across the fields of mathematics, science and computing, and nursing, business courses have not been explored. The purpose of this paper is to report on a case study designed to investigate the key multimodal academic literacy and numeracy practices of ten international Master of Commerce Accounting students enrolled at an Australian university. Specifically, it aims to provide an account of the salient textual and the logical patterns through the analysis of cohesive devices in a key topic in the Principles of Finance course, namely capital budgeting techniques and management reports.

This study is pertinent as most international ESL/EFL students' enrolments in Australia and elsewhere is in business programs. This study is underpinned by Halliday's (1985) Systemic Functional Linguistics (SFL) approach to language and Halliday and Hasan's (1976) cohesion analysis scheme. The study employs a Systemic Functional Multimodal Discourse Analysis (SF-MDA) for the analysis of cohesive devices in the participants' multimodal texts. Lexical cohesion formed the largest percentage of use, and in particular repetition of the same lexical items, followed by reference.The findings contribute to the description of the meaning-making processes in these multimodal artefacts. They provide a potential research tool for similar investigations across a broad range of educational settings. Implications of the findings for finance students and educators are finally presented.
\end{abstract}


Keywords: literacy practice; cohesion analysis; Systemic Functional Linguistic; SFL; SF-MDA; discourse analysis; finance; business discourse; finance literacies

\section{INTRODUCTION}

Constellations of cohesive features in business discourse are important to the maintenance of style and thread texts. Research studies on finance students' literacy and numeracy practices, however, has been mostly directed at the empirical studies of major and non-major students' performance in Principles of Finance courses (Sen, Joyce, Farrell, \& Toutant, 1997) and the effect of class attendance on students' performance (Chan, Shum, \& Wright, 1997). Similarly, research studies in accounting have investigated the readability of accounting narratives in financial accounting textbooks over the past years, as measured by word and sentence length (Davidson, 2005) and lexical choices as measured by word choice and frequency of use (Conaway \& Wardrope, 2010; Hyland, 1998; Rutherford, 2005).

Whereas few research studies have investigated the use of cohesive devices in tertiary business courses (Fazelimanie, 2004; Johns, 1980; Nga, 2012), a dearth of research studies explored its use in academic texts written by Arab ESL/EFL students (Abusharkh, 2012; Al Jarf, 2001; Alharbi, 2011; Aljabr, 2011; Alshammari, 2011; Hinkel, 2001; Kamal, 1995; Khalil, 1989; Mohamed-Sayidina, 2010; Mohamed \& Omer, 2000). Multimodal communication research in tertiary contexts has been conducted across the fields of mathematics (de Oliveira \& Cheng, 2011; Guo, 2004; O'Halloran, 1996, 1999, 2000, 2004, 2005, 2008; 2009), science and computing (AlHuthali, 2007; Alshammari, 2011; Drury, O' Carroll, \& Langrish, 2006; Jones, 2006; Wake, 2006), and nursing (Okawa, 2008). As Lea and Street (2006) state, multimodal analysis reveals the range of meanings expressed in learners' activities and genres. Similarly, Pauwels (2012, p. 250) argues "multimodal analysis not only takes different modes into account but also has a strong focus on the effects of their interplay" between images and texts. The importance of examining the cohesive features in postgraduate Business students' multimodal texts becomes pertinent since they are vital for the maintenance of style and thread texts.

The purpose of this paper is to report on a case study designed to investigate the key dynamic multimodal academic literacy and numeracy social practices of 10 first-year Master of Commerce Accounting students at an Australian university. Students enrolling in this program are required to achieve six or more in the IELTS. The participants were enrolled in the Principles of Finance course, and they were given the pseudonyms: Abdulhadi, Saud, Jim and Cathy (Group 1), Abdulrahman and Jiang (Group 2), and Ibrahim, Hasan, Sharon and Tracey (Group 3). The main aim of this study is to explore and analyse the use of cohesive devices in postgraduate 
Business students' multimodal key texts in the Principles of Finance course, namely capital budgeting techniques and management reports, by investigating the interrelated dimensions of multimodal texts, multisemiotic resources, academic literacy and numeracy practices, and contexts in the key topic in the business course. Specifically, it aims to investigate the participants' socio-cultural situated multimodal meaning-making processes in texts and financial tables and graphs.

The research study employs a Systemic Functional Multimodal Discourse Analysis (henceforth SF-MDA) tool to explore the participants' multimodal academic literacy and numeracy practices. This tool is based on Halliday's (1985; Halliday \& Matthiessen, 2004) Systemic Functional Linguistics (hereafter SFL).

What follows is a review of key theorists in academic literacy research and the literature relevant to academic literacy research studies, in particular Halliday's SFL theory and the previous research studies on SF-MDA. It also explores studies related to the analysis of mathematical symbolism and the literacy and numeracy practices of Business program students.

\section{LITERATURE REVIEW}

Literacy practices are multifarious, proliferating and ever changing with social contexts and cross-cultural diversity. Multisemiotic resources include the visual including the wide array of diagram genres, the written, the auditory, and the haptic. A multiliteracies model (Cazden et al., 1996; Cope \& Kalantzis, 2000, 2013; Kalantzis \& Cope, 2012) takes into account the multimodal social literacy practices that are contested around material acts of meaning. Prince and Perren and Grant (2000), for example, studied the development of management accounting by exploring the idiosyncratic accounting knowledge and the effects of its transmission over the history of small firms. Concepts like transmission, strategies, assimilation, retention, internalisation, externalisation, and construction of knowledge often characterise research studies that are framed by the cognitive linguistic or socio constructivist frameworks. Since the internal learning mechanisms of individual learners are unobservable, the present study is framed by the sociocultural model of learning, which emphasise the importance of social processes.

As this study construes Academic literacies as set of socially situated multimodal literacy and numeracy social practices, we present a review of the literature which takes social semiotics, SFL, and multimodal academic literacies approaches into account. Archer (2008, pp. 72-73) proposes the term 'academic numeracy practices' in order to "emphasise the socially situated nature of all practices". Writing is perceived as a social process of formulating (or negotiating) meaning whereby ideas are explored, clarified, and 


\section{VOLUME 8}

reformulated, i.e. through semiotic mediation. Halliday's concept of openended meaning making semiotic potential (or language as a system) is the foundation of his SFL approach. Language consists of a set of finite interlocking systems of semantic choices, which are realised in wordings, or lexico-grammatical structures: in vocabulary and syntax. Although the actual texts we process and produce are limited, the potential is unlimited as we usually interact with a new text, go through semiotic mediation of the text, and then produce a text that is aligned with our socio-cultural context.

SFL provides a wide range of linguistics resources for handling and interpreting multimodal socio-cultural literacy events which are mediated by written texts (Halliday, 1985). The core of these resources is the lexicogrammatical stratum of language which is used to explore the three language metafunctions that construe meaning ideationally, by representing and ordering our experience, perceptions, consciousness, and the basic logical relations (oriented towards the field of discourse), interpersonally, by enacting certain social relationships (oriented towards the tenor of discourse), and textually, by weaving ideational and interpersonal meanings into a textual whole (oriented towards the mode of discourse). These metafunctions correlate respectively with three register semiotic variables: FIELD (what is talked about?), TENOR (how social roles and identities are constructed?), and MODE (How are the meanings organised).

O'Toole (1994) was the first to utilize SFL in multimodal discourse analysis; in his book The Language of Displayed Art. Kress and van Leeuwen (1996) who first developed a model for the analysis of textual organization within images and layout. They have applied SFL in interpreting the multisemiotics that contribute to meaning making. SFL-based research in multimodal communication and representation has been confined to school and workplace contexts. In her book The Handbook of Business Discourse, Bargiela-Chiappini (2009) reviews a range of business discourse studies in workplace settings. Thomas (1997), for example, investigated the linguistic structures in a series of management messages in the annual reports of a company. Camiciottoli (2010) found that discourse conjunctive devices in financial disclosure texts were more frequent in the earnings presentations than in the earnings releases, suggesting their pragmatic use influences the interpretation of the message. Whereas multimodal communication research in tertiary contexts has been conducted across the fields of mathematics (de Oliveira \& Cheng, 2011; Guo, 2004; O'Halloran, 1996, 1999, 2000, 2004, 2005, 2008; 2009), science and computing (AlHuthali, 2007; Alshammari, 2011; Drury et al., 2006; Jones, 2006; Wake, 2006), and nursing (Okawa, 2008), tertiary business discourse has not been explored. As Garzone (2009, p. 156) points out that "so far, contributions from linguists specifically dealing with multimodality in business discourse have been relatively few". This study is pertinent as most international ESL/EFL students in Australia and elsewhere are enrolled in business and commerce programmes (Author). It is 
part of a larger investigation into the literacy experiences of 19 Master of Commerce international students at a South Australian university ( Author, 2014).

Johns (1980), Fazelimanie (2004), and Nga (2012) employed Halliday and Hasan's (1976) scheme to investigate the use of cohesive devices in business texts. The findings showed that the most frequent cohesive device was lexical cohesion. Whereas conjunction was the second most common category in Fazelimanie's study, in Johns' study it was reference. Substitution and ellipsis occurred very infrequently in the two studies. The preponderance of cohesive devices, however, is not always an indicator of a contextualised cohesive text. As cohesion is part of the system of a language, it depends on both the selection of the cohesive devices and on "the presence of some other element which resolves the presupposition that this sets up" (Halliday \& Hasan, 1976, p. 5). Alshammari's (2011) study showed that lexical repetition constituted $75 \%$ of lexical cohesion uses in the Nano technology students' reports. The data revealed that both repetition and collocation were used instead of reference items. Kamal (1995) investigated the types and sub-types of devices that are the most frequent in English and Arabic texts. It was found that in spite of the apparent one-to-one correspondences (86\%) between the two languages in most of the cohesive instances there were many discrepancies. Kamal argues that Arab students resort to repetition only in cases of potential ambiguity as to which NP a reference item refers. These findings were confirmed by Mohammed and Omar's (2000) study. Along similar lines, Mohamed-Sayidina's (2010) study aimed to test her hypothesis that ESL Arab students transfer the rhetorical strategies used in native Arabic texts when writing in English. The findings showed the predominance of repetition of the same noun and additive transitions, the lack of substitution or ellipsis, the apparent deficiency in the use of adversative transitions, and the use of personal reference (85\%) and demonstrative reference (15\%). Author (2013) investigated the multimodal experiential meanings in ESL/EFL students' management reports; though he did not explore the use of cohesive devices. Although management reports utilising capital budgeting techniques are one of the most commonly used genres in finance, there is a lack of text-based investigations that explore and analyse the use of cohesive devices in these texts.

The reviewed literature above reveals the lack of research investigating the use of cohesive devices by ESL/EFL postgraduate Master of Commerce Accounting program students. Such research could shed light on the practices and discourses which constitute financial knowledge.

As the paper aims to investigate the way international postgraduate business ESL/EFL students construct cohesive texts, it is pertinent to provide an overview of the system of cohesion. 


\section{COHESION}

A cohesive relation is defined by Halliday and Hasan (1976, p. 8) as "the semantic relation between an element in the text and some other element that is crucial to the interpretation of it". Hasan (1985) states that coherence exists in a text when 'meaning relations' are realised by cohesive ties or chains (or the lexical and the grammatical patterns) that allow sentence sequence to be understood as connected discourse. Cohesion consists in the continuity of lexico-grammatical meaning and semantic connection with a preceding text. Halliday and Hasan (1976, p. 26) argue that cohesion "does not concern what a text means; it concerns how the text is constructed as a semantic edifice". They list five types of cohesion: reference, substitution, ellipsis, conjunction, and lexical cohesion.

While the first three types are expressed through the grammar, lexical cohesion is expressed through the lexis, and conjunction is "mainly grammatical, but with a lexical component in it" (ibid, p. 6), i.e. it contains ties that are both grammatical and lexical. Unlike THEME/RHEME, cohesion is a non-structural system since it links "elements that are structurally unrelated to one another" (ibid, p. 27) to create a unified, coherent text. Halliday and Matthiessen (2004, p. 579) argue that "structural and cohesive resources work together in the marking of textual transitions and in the marking of textual statuses" as shown below.

\section{Table 1.Textual resources}

\begin{tabular}{|c|c|c|}
\hline & Structural & Cohesive \\
\hline \multirow{2}{*}{$\begin{array}{l}\text { Textual } \\
\text { transitions } \\
\text { [órganic'] }\end{array}$} & \multirow[t]{2}{*}{ (clause complex $=>$ logical) } & CONJUNCTION \\
\hline & & \multirow{2}{*}{ LEXICAL COHESION } \\
\hline \multirow{2}{*}{$\begin{array}{l}\text { Textual statuses } \\
\text { ['componential'] }\end{array}$} & \multirow{2}{*}{$\begin{array}{l}\text { THEME: } \text { Theme }^{\wedge} \text { Rheme; } \\
\text { INFORMATION: } \\
\text { Given + New }\end{array}$} & \\
\hline & & $\begin{array}{l}\text { REFERENCE; ELLIPSIS/ } \\
\text { SUBSTITUTION }\end{array}$ \\
\hline
\end{tabular}

(Adapted from Halliday \& Matthiessen, 2004, p. 579)

Whereas conjunctions are concerned with textual transitions that form logical relations of clause complexing, the other cohesive resources (THEME, INFORMATION structure, reference, ellipsis, and substitution) are concerned with textual statuses that form textual cohesion between Theme and Information. Due to space constraints we investigate here only the five types of cohesion. Due to space constraints we investigate here only the five types of cohesion in a key topic in finance, namely reference, substitution, ellipsis, conjunction, and lexical cohesion. 
Table 2. The five types of cohesive devices

\begin{tabular}{|c|c|c|c|}
\hline Metafunction & Component & Annotation Code & Sub-Components \\
\hline Experiential & $\mathrm{L}=$ Lexical & [L: Sub-Component] & $\begin{array}{l}\text { Synonym= Syn., } \\
\text { Antonym= Ant., } \\
\text { Repetition= Rep., } \\
\text { Hyponym= Hyp., } \\
\text { Meronym= Mer., } \\
\text { hypernym = Hyper. }\end{array}$ \\
\hline \multirow[t]{3}{*}{ Logical } & \multirow[t]{3}{*}{$\begin{array}{l}\mathrm{C}= \\
\text { Conjunctive }\end{array}$} & \begin{tabular}{|l} 
[Elaboration: Sub- \\
Component]
\end{tabular} & $\begin{array}{l}\text { Apposition= Appos., } \\
\text { Clarification= Clari. }\end{array}$ \\
\hline & & $\begin{array}{l}\text { [Extension: Sub- } \\
\text { Component] }\end{array}$ & $\begin{array}{l}\text { Additive }=\text { Add., } \\
\text { Adversative= Advers., } \\
\text { Variation= Variat. }\end{array}$ \\
\hline & & $\begin{array}{l}\text { [Enhancement: Sub- } \\
\text { Component] }\end{array}$ & $\begin{array}{l}\text { Manner= Man., } \\
\text { Temporal=Temp., Causal= } \\
\text { Caus., Concession= Conc. }\end{array}$ \\
\hline Textual & $\begin{array}{l}\mathrm{R}= \\
\text { Referential }\end{array}$ & [R: Sub-Component] & $\begin{array}{l}\text { Cataphoric= Cat., } \\
\text { Anaphoric= Ana., Definite } \\
\text { Article= Def., } \\
\text { Demonstrative= Dem., } \\
\text { Pronoun= Pro., Possessive= } \\
\text { Poss., Comparative= } \\
\text { Comp. }\end{array}$ \\
\hline Textual & $\begin{array}{l}\text { Substitution } \\
\& \text { Ellipsis }\end{array}$ & [Subs.], [Ellip.] & $\begin{array}{l}\text { Substitution= Subs., } \\
\text { Ellipsis= Ellip. }\end{array}$ \\
\hline
\end{tabular}

Unlike reference and ellipsis, lexical cohesion does not only include components of messages, but also creates relations between whole messages, as do conjunctions. Conjunctive textual cohesion is captured through two types of logical-semantic relations that guide the rhetorical development of a text: expansion and projection. The projection relation is formed out when the secondary clause projects through the primary clause, thereby instantiating it as a locution (wording) or an idea (meaning). Expansion is formed out when the secondary clause expands the primary clause through the use of one of the three main sub-types of expansion: elaboration, extension, and enhancement (ibid, p. 540). It is formed out of a mixture of paratactic (equal status) or hypotactic (unequal status) interdependency nexus. A paratactic relation is set up when two or more independent clauses are connected by conjunctive devices, while a hypotactic relation is set up when a dependent clause is connected to an independent (dominant) clause by a conjunctive device. Reference includes three types: personal, demonstrative and comparative. 
Endophoric reference, unlike homophoric and exophoric reference, is retrievable from within the text (Eggins, 2007). It can be of three kinds: anaphoric, cataphoric, or esphoric. Anaphoric reference occurs when the referent precedes the cohesive device. Whereas the referent follows the cohesive device in another sentence in cataphoric reference, it follows the cohesive device within the same nominal group/noun phrase in esphoric reference.

\section{DATA AND METHOD OF ANALYSIS}

The corpus was composed of three group assignments (7,844 words) on a key topic in the Principles of Finance course, capital budgeting techniques and management reports: text 1 (2,483 words), text 2 (1,975 words), and text 3 (3,386 words), excluding the cover sheet, table of contents and the appendices. The assignment was allotted $15 \%$ of the total mark for this course. Each one was written by a group of 2-4 international ESL/EFL students: Abdulhadi, Saud, Jim and Cathy (Group 1), Abdulrahman and Jiang (Group 2), and Ibrahim, Hasan, Sharon and Tracey (Group 3). Henceforth, each group will be referred to by the group numbers. Though the three groups had different assignment task sheets, they were comparable since the main topic underlying the tasks is similar, except for the second part of the Group 1 task sheet (portfolio management) which was excluded.

As the management reports comprised multimodal data, we used the nomenclature Systemic Functional Multimodal Discourse Analysis (SFMDA) to explore the peculiar aspects related to the organisation of meaning. The SF-MDA drew on Halliday and Hasan (1976) and Halliday and Matthiessen's (2004) framework for the analysis of cohesion. Types of cohesive devices and their sub-components were identified and annotated (Table 2) in order to calculate the frequency of occurrence of each type across the three texts. The SF-MDA of the use of cohesive devices was conducted according to the analysis tools outlined below.

On the logical level conjunctive cohesion is captured using the three main types of elaboration, extension, and enhancement. Finally, on the textual level the texts were analysed for the use of reference, substitution and ellipsis. While an intrasentential reference relates two parts of a single sentence, intersentential reference relates two sentences together, thereby contributing to the overall discourse organisation.

Frequencies were converted into percentages in order to facilitate comparability among the three groups. The use of numerical/quantitative data in this qualitative research aims to make statements such as "more," "most," and "equal" more precise.

What follows is the SF-MDA of the finance texts. 
Table 3. Cohesion analysis tools

\begin{tabular}{|c|c|c|c|}
\hline \multicolumn{2}{|c|}{ Metafunction } & Aim: To investigate ... & Analysis Tools \\
\hline \multirow{2}{*}{ 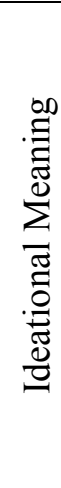 } & $\begin{array}{l}\text { Experienti } \\
\text { al }\end{array}$ & $\begin{array}{l}\text { (a) The logical relationships } \\
\text { students enter into. }\end{array}$ & $\begin{array}{l}\text { Lexical Cohesion } \\
\text { (Halliday \& Hasan, } \\
\text { 1976): Reiteration } \\
\text { (repetition, hyponyms, } \\
\text { meronyms, synonyms, \& } \\
\text { antonyms) }\end{array}$ \\
\hline & Logical & $\begin{array}{l}\text { The "relations between } \\
\text { external phenomenon" } \\
\text { (Halliday \& Hasan, 1976, p. } \\
\text { 240) that express the logical } \\
\text { relationship that they signal. }\end{array}$ & $\begin{array}{l}\text { Cohesion (Halliday \& } \\
\text { Hasan, 1976; Halliday \& } \\
\text { Matthiessen, 2004): } \\
\text { External conjunctions } \\
\text { (C1i) }\end{array}$ \\
\hline \multirow{4}{*}{ 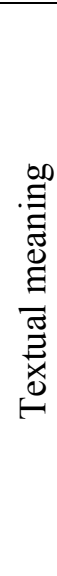 } & \multirow{4}{*}{ 焉 } & \multirow[t]{2}{*}{$\begin{array}{l}\text { The organization of the } \\
\text { propositional content } \\
\text { (ideational function). }\end{array}$} & $\begin{array}{l}\text { Reference (anaphor): } \\
\text { Intersentential (R1): } \\
\text { Personal, Demonstrative } \\
\text { \& Comparative }\end{array}$ \\
\hline & & & $\begin{array}{l}\text { Reference (anaphor): } \\
\text { Intrasentential (R2): } \\
\text { Personal, Demonstrative } \\
\text { \& Comparative }\end{array}$ \\
\hline & & $\begin{array}{l}\text { Frequency and top key } \\
\text { words }\end{array}$ & $\begin{array}{l}\text { Lexical Density: } \\
\text { Textalyser (2004) }\end{array}$ \\
\hline & & Organisation of the text. & $\begin{array}{l}\text { Ellipsis/ Substitution } \\
\text { (clause, word group), } \\
\text { Collocations }{ }^{1}\end{array}$ \\
\hline
\end{tabular}

\section{AN SF-MDA OF COHESION IN THE FINANCE TEXTS}

Both Groups 1 and 3 were far over the maximum word limit of 2000 words. Group 2's mark in this report was the highest, 88 out of 100, compared with 72 and 78 for Group 1 and Group 3 respectively. All the three groups used tables as tools to clarify their calculations for the investment proposals and to facilitate comparability among the investment proposals. Group 1

${ }^{1}$ Collocations only refer to the probability of co-occurrence of lexical items, rather than to semantic relations between words. Collocations were not analysed since their occurrences take the form of lexical strings and 'reiteration' accompanied by 'the' or a demonstrative that are already accounted for in the analysis (Halliday \& Hasan, 1976, pp. 287-288). 


\section{VOLUME 8}

excessively used tables and graphs compared to the other two groups. This may explain the reason why it has exceeded the required number of words by $25 \%$. The three assignments encompassed 46 tables and 17 graphs.

The cohesive devices used in the three assignments were analysed and compared. The table below presents the numbers and percentages of the different subcategories of grammatical and lexical cohesive ties identified in the three texts.

Table 4. Types of cohesive ties in the three texts

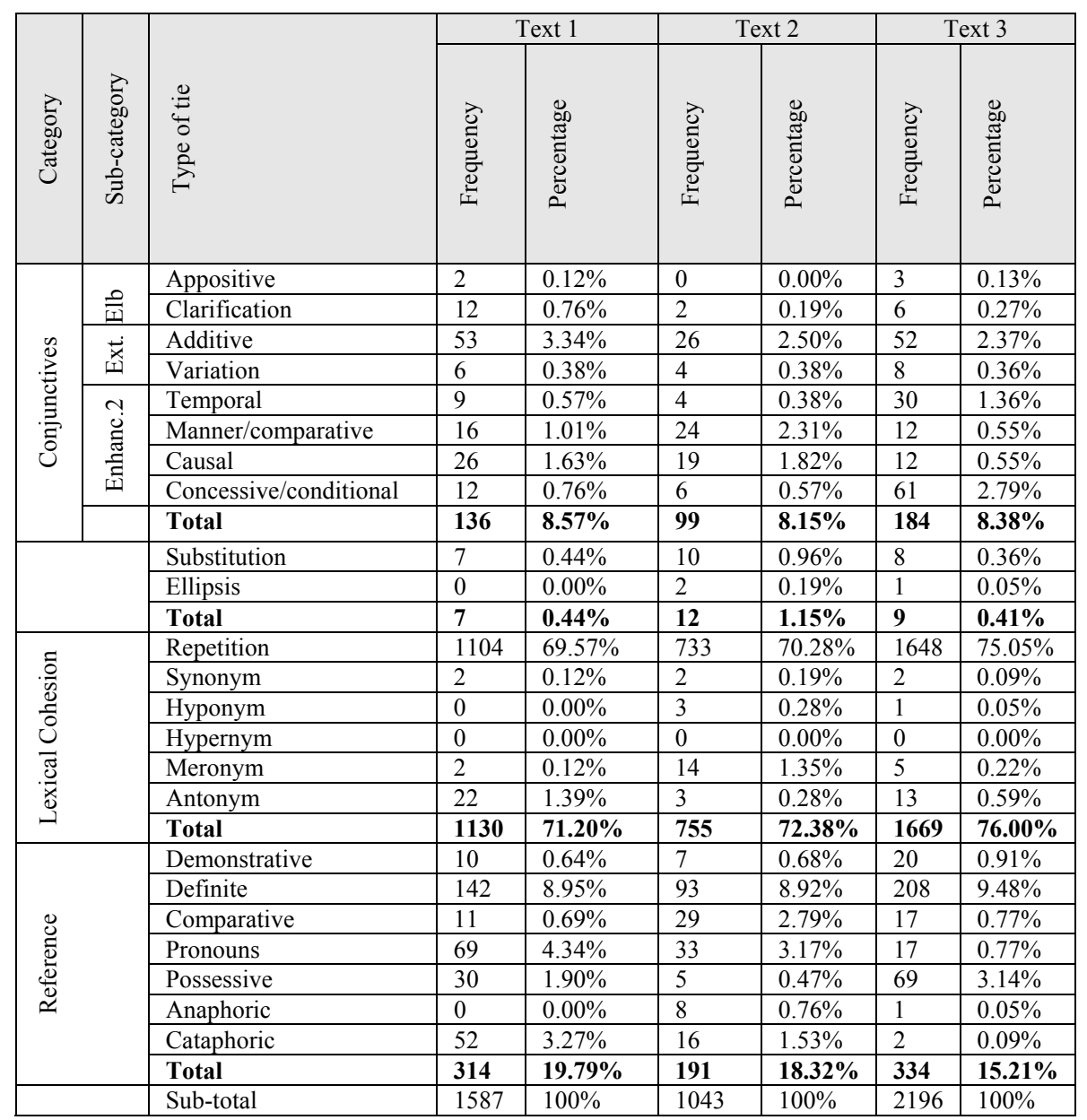

Lexical cohesion was the most frequently occurring cohesive type in the three texts $(<76 \%$ of the total cohesive devices), and in particular reiteration of the same lexical items $(<75.05 \%)$, as shown in the table above. Taxonomic

${ }^{2}$ Enhanc. $=$ Enhancement, Ext. $=$ Extension, Elb. $=$ Elaboration 
classifications of synonyms, hyponyms, hypernyms, meronyms, and antonyms play a major role in the organisation of financial statements' discourse. Hyponymy is a sign whose denotation class is properly included in the denotation class of another sign. It refers to a general class with its subclass. A meronym, on the other hand, denotes a part (Board, NPV) in respect to a lexical item denoting a whole. A hypernym refers to the lexeme with the more general or inclusive meaning. For example, the more general (or superordinate) lexeme 'Week' is a hypernym of the sub-classes 'Saturday' and 'Sunday' which are hyponyms of their general class 'Week'. 'Advertising costs', 'Bulb costs, and 'Electricity costs' are meronyms of the sub-class 'Costs' since the sum of these categories represent 'Costs' which is in turn a hyponym of 'Liabilities'. The second most frequently occurring lexical cohesive device is antonymy $(<1.39)$ : preferred/common stocks, increase/decrease, old/new, buy/sell, inflows/outflows, positive/negative. Reference was the second most common category in the texts $(<19.79 \%)$ : for example, the demonstrative 'the', the pronoun 'it', and the possessive 'its'. The frequency of occurrence of the lexical cohesive devices in Group 3's text (76\%) exceeded those in Groups 1 and 2's texts $(71.20 \%$ and $72.38 \%$ respectively), though it is hard to draw any conclusions since text length was unequal in the three management reports. However, the cohesive density index showed that Group 1's use of cohesive devices was almost equal to that of Group 3, as shown below.

Table 5.Cohesive density index in the three texts

\begin{tabular}{|l|c|c|c|}
\hline \multicolumn{1}{|c|}{ Group } & One & Two & Three \\
Category & & & \\
\hline Word count & 2483 & 1975 & 3386 \\
\hline Number of ties & 1587 & 1043 & 2196 \\
\hline Ratio of ties/100 words & $63.91 \%$ & $52.81 \%$ & $64.85 \%$ \\
\hline
\end{tabular}

Cohesive density was calculated by dividing the total number of content words by the total word count and then multiplying the result by one hundred.The finding of the index of cohesive density revealed that Group 1 (63.91 cohesive devices per 100 words) and Group 3 (64.85 cohesive devices per 100 words) had higher ratio than Group 2 (52.81 cohesive devices per 100 words).

Both Group 1 and Group 2 used the cataphoric reference items colon, asterisk, and 'below' to refer readers to a following text. Group 1 used colons thirty-six times in sub-headings as it preferred to repeat each calculation three times according to the number of projects rather than merging all in one subheading as the other groups did. The group also used the cataphoric reference 


\section{VOLUME 8}

'below' six times to refer the reader to the graph. Group 2 used the asterisk three times as a cataphoric reference marker to refer to a following note. Substitution and ellipsis rarely occurred in the three texts ( $\mathrm{n}=$ less than $1.16 \%$ ).

Conjunctives "help readers interpret pragmatic connections" in relation to the writer's thinking and "express semantic relation between clauses" (Hyland, 1998, p. 228). All the three groups almost equally used paratactic (co-ordinating) and hypotactic (subordinating) nexuses to extend the propositions, and in particular additive conjunctions which had the highest frequency in the three texts, compared to variation conjunctions. Whereas extension adds to or varies a clause message and enhancement expands the utterance by providing circumstantial details such as time, place, manner, cause or condition, elaboration expands an utterance by reformulating the message, as in:

If [C: Enhancement: Cond.] sales price is set 30\% above its expected price the NPV would be +5,000,000). (Group l's text, Line 49)

After the derivation of cash flows NPV is calculated and [C:

Extension: Add.] it accounted for 5,304,861 \$ and [C: Extension: Add.] it is indeed [C: Elaboration: Clari .] massively greater than the NPV of proposal 1 which only [C: Extension: Variat.] accounts for 2,853,108\$. (Group 1's text, Line 131)

Therefore [C: Enhancement: Caus.] incremental cash flows are calculated for 325,000 for the years 2009 and 2010. (Group 1 's text, Line 171)

Most of the conjunctive conditional devices in Groups 1 and 3's texts were found in the interpretation of graphs. In the second example above, Group 1 used the paratactic nexus 'and' to link two equally important ideas. The group also used the device 'indeed' to emphasise their point of view. This was achieved by comparing the NPV of proposal 2 to that of proposal 1 . Antithesis was expressed by using the variation device 'only'. The group expanded a proposition in the third example through the use of causal conjunctive device 'therefore'. Other examples from Group 2 and 3's texts are listed below:

We then [C: Extension: Add.] compute the other income at base case [derived from sale of bottles by dividing the no of sessions by 5 (as [C: Enhancement: Man.] stated in question) and [C: Extension: Add.] multiplying by contribution of \$2 per bottle: (Group 2's text, Line 16) 
MULTIMODAL WRITTEN TEXTS:

AN SF-MDA OF A KEY TOPIC IN FINANCE

Firstly, [C: Enhancement: Temp.] all cash flows are calculated incremental cash flows at the end of each year. (Group 3 's text, Line 21)

For example, [C: Elaboration: Appos.] Incremental Adelaide factory leasing revenue and [C: Extension: Add.] incremental cost saving are obvious positive correlation factors. (Group 3 's text, Line 86)

Group 3 used more temporal conjunctives (firstly, secondly, thirdly, etc) to signpost the sequential structure of an argument. Although the additive device 'and' in each sentence below was annotated as an extending device, it is treated as an elaborating in sense since it was followed by 'this' to refer back to a proposition in the previous clause:

After the derivation of cash flows //NPV is calculated// and it accounted for 2,853,108// which are positive// and [C: Extension: Add.] this [R: Dem.] implies that proposal is creating value. (Group 1 's text, Sentence 61)

Firstly,// according to Australian labour law,// the company must pay redundancy package \$2.5 M to Adelaide Factory's employees,// and [C: Extension: Add.] this [R: Dem.] incremental outflow would equal to approximately 3.8\% of Adelaide annual sales contribution. (Group 3 's text, Sentence 37)

As reiteration of the same lexical items was the most frequently $(>69 \%)$ occurring cohesive device in the three texts, it is pertinent to calculate the most frequently used key words. Using the text analysis web tool Textalyser (2004), these words are listed in the table below according to their frequency.

While the top key word in Text 1 and 3 was 'cost', it was 'year(s)/ $\operatorname{Yr}(\mathrm{s})$ ' in Text 2. The word NPV was one of the top 6 key words in Group 2 and 3's texts. The word "year' in text 2 was abbreviated "Yr(s)" 55 times $(5.1 \%)$ in the tables and used 7 times $(0.7 \%)$ in the text. Group 1 used the phrase " first/old machine" and "new machine" to refer to each investment proposal, Group 2 used the phrase "dome unit" and "tanning bed", and Group 3 used the phrase "proposal 1", "proposal 2", and "proposal 3". Interestingly, the non-conceptual word 'table' was used 30 times in text 1. As explained earlier, Group 1 preferred to represent the findings of each investment proposal separately.

To sum up, the analysis of cohesion and word frequency count revealed respectively the differences in the relative number of cohesive ties and the most frequently used key words used by each group. The SF-MDA of register in the finance module was supplemented with cohesion analysis since the two 


\section{VOLUME 8}

define the text. As Halliday (1985, p. 339) states, for a text to be coherent "it must deploy the resources of cohesion in ways that are motivated by the register of which it is an instance". Next, I present the findings of the SFMDA of a statistical graph.

Table 6.Frequency and top key words in the three texts

\begin{tabular}{|c|c|c|c|}
\hline Text & Word & Instances & Frequency \\
\hline \multirow[t]{6}{*}{ One } & cost & 46 & $3.7 \%$ \\
\hline & cash & 38 & $3.1 \%$ \\
\hline & net & 36 & $2.9 \%$ \\
\hline & machine & 34 & $2.7 \%$ \\
\hline & table & 30 & $2.4 \%$ \\
\hline & flows & 27 & $2.2 \%$ \\
\hline \multirow[t]{6}{*}{ Two } & year(s)/Yr(s) & 62 & $5.8 \%$ \\
\hline & tanning & 40 & $3.7 \%$ \\
\hline & unit & 30 & $2.8 \%$ \\
\hline & dome & 28 & $2.6 \%$ \\
\hline & bed & 19 & $1.8 \%$ \\
\hline & npv & 16 & $1.5 \%$ \\
\hline \multirow[t]{6}{*}{ Three } & cost & 68 & $4.0 \%$ \\
\hline & proposal & 59 & $3.4 \%$ \\
\hline & npv & 40 & $2.3 \%$ \\
\hline & company & 38 & $2.2 \%$ \\
\hline & Adelaide & 33 & $1.9 \%$ \\
\hline & incremental & 33 & $1.9 \%$ \\
\hline
\end{tabular}

\section{Cohesion analyses of a statistical graph}

Both Group 1 and Group 3 applied their knowledge of the theoretical aspects in finance in order to construct statistical graphs that encompass a complex array of elements and processes (Monteiro \& Ainley, 2006). Group 2 , on the other hand, preferred to present the findings in tables. Group 1's intuitive interpretations of the graph was utilised for conducting the SF-MDA. This interpretation showed that meaning in visual semiotic resources is created not only intra-semiotically (i.e. within the graph) but also intersemiotically through the interaction of the graph and the accompanying linguistic text (O'Halloran, 2008). The intersemiotic relation that existed between the tables and graphs and the text accompanying them was that the latter helps in elucidating and realising the highly condensed accounting numeracy. This text was therefore subordinate to the tables or graphs through 
the use of endophoric markers (colon, see Figure, as in ...). The tables and the graphs were integrated in the text flow through the use of cross-references 'Figure' and 'Table'. However, since the text added new information based on the findings in tables or graphs a logico-semantic relation of extension (Martinec \& Salway, 2005) exist between the tables/graphs and the texts accompanying them, as the latter provide new information based on the content of the former.

Group 1 and Group 3 presented their mathematical findings through a sensitivity analysis graph, a measure which focuses on analyzing the effects of changes in key variables (that may be influenced by market conditions) on the project's IRR or NPV. Group 1, for example, assumed that revenues will increase or decrease to the extent of $30 \%$ in WACC, machine cost, sales, and COGS.

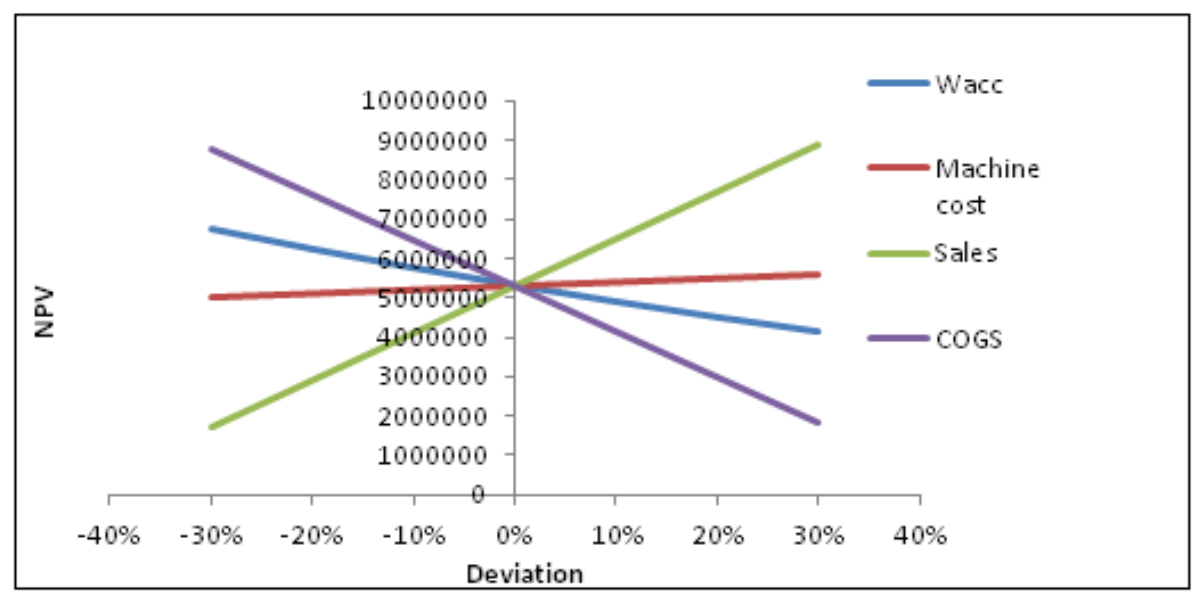

Figure 1.Group 1's Sensitivity analysis graph

The two groups used abbreviations and acronyms (WACC for weighted average of capital cost and COGS for cost of goods sold) and shapes (arrows, squares and diamonds) to label the axes in graphs. In Group 1's graph above, the Net Present Value (NPV) was based on four key variables: WACC, machine cost, sales, and COGS. Royce (2002, p. 193) argues that visual semiotic systems "utilize meaning-making resources in ways that are specific to their particular mode". The underlying meanings were found in the reasoning this material form exhibit. To interpret the sensitivity graph above, the participants did not only need to understand the lexicogrammar of the axes but also its relation to the intersecting axes that depicts the mathematical relation (Author, 2013).

The slopes of the lines in the graph above indicate how sensitive NPV is to changes in each input: "the larger the range, the steeper the variable's slope and the more sensitive NPV is to this variable" (Brigham \& Houston, 2009, p. 


\section{VOLUME 8}

377). Each slope is analysed in terms of its degree of steepness, in which steep curves indicate a higher degree of sensitivity to deviations from the original estimates. The statistical analysis shows that

NPV is very sensitive to changes in Sales and COGS, fairly sensitive to changes in WACC, but not very sensitive to changes in Machine Costs... For example, the Sales slope can be intuitively interpreted in natural language as "sales will probably deviate highly from the original estimates" and "Machine Costs will probably not deviate from the original estimates”. (Author, 2013, p.xx)

The Group 1 intuitive verbal interpretations (or readings) of the graphs were analysed for the use of implicit cohesive devices. For example, the SFMDA of Group 1's sensitivity analysis graph above is shown in the table below.

Table 7.Cohesion analysis of the Group 1 intuitive interpretation of the sensitivity analysis graph

\begin{tabular}{|l|l|}
\hline 231. & $\begin{array}{l}\text { When all of the inputs are set at their [R: Pos.] base-case levels, } \\
\text { their } \\
\text { [R: Poss.] deviations from the [R: Def.] base are all zero and } \\
\text { [C: Extension: Add.] the [R: Def.] NPV [L: Rep.] is \$ 5,304,861. }\end{array}$ \\
\hline 232. & $\begin{array}{l}\text { If [C: Enhancement: Cond.] sales [L: Rep.] price [L: Rep.] is set } \\
\text { 30\% above its [R: Poss.] expected [L: Rep.] price [L: Rep.] the } \\
\text { [R: Def.] NPV [L: Rep.] would be +\$9,000,000. [L: Rep.] }\end{array}$ \\
\hline 233. & $\begin{array}{l}\text { If [C: Enhancement: Cond.] WACC [L: Rep.] price [L: Rep.] is } \\
\text { set } \\
\text { [L: Rep.] 30\% [L: Rep.] above its [R: Poss.] expected [L: Rep.] } \\
\text { price [L: Rep.] the [R: Def.] NPV [L: Rep.] would be } \\
\text { +\$6,500,000. } \\
\text { [L: Rep.] }\end{array}$ \\
\hline 234. & $\begin{array}{l}\text { If [C: Enhancement: Cond.] machine [L: Rep.] cost [L: Rep.] price } \\
\text { [L: Rep.] is set [L: Rep.] 30\% [L: Rep.] above its [R: Poss.] } \\
\text { expected [L: Rep.] price [L: Rep.] the [R: Def.] NPV [L: Rep.] } \\
\text { would be +\$5,500,000. [L: Rep.] }\end{array}$ \\
\hline 235. & $\begin{array}{l}\text { If [C: Enhancement: Cond.] COGS [L: Rep.] price [L: Rep.] is set } \\
\text { [L: Rep.] 30\% [L: Rep.] above its [R: Poss.] expected [L: Rep.] } \\
\text { price [L: Rep.] the [R: Def.] NPV [L: Rep.] would be \$8,800,000. } \\
\text { [L: Rep.] }\end{array}$ \\
\hline
\end{tabular}

The cohesion analysis findings showed that the most frequent cohesive device was lexical cohesion $(\mathrm{L}=31)$, followed by reference $(\mathrm{R}=12)$ and conjunctions $(\mathrm{C}=5)$. Group 1's interpretation of the graph employed both 
demonstrative (the) and possessive (their/its) determiners. The word 'inputs' in sentence 231 above acted as the referent of the possessive determiner 'their'. The specific determinative Deictic 'the' is a reduced form of that as preserved its initial part (Halliday \& Matthiessen, 2004). It is not surprising that the symbol ' $\%$ ' was repeated 4 times in the interpretation of the graph since its rhetorical structure, unlike academic texts, is not bound by linearity. Finally, the conjunctive conditional/causal relations ('if ..., then') contributed to the enhancement of meaning. The four dependent $-\beta$ clauses in sentences 232-235 aim to contextualise the discourse for the independent clauses, thereby providing further related information. be... $\|$

|| If ... is set $30 \%$ above its expected price [X $\beta 1-4] \|$, the NPV would

The four results in the independent clauses are dependent on the cause expressions, which are determined by increase as well as decrease in key variables to the extent of $10 \%$ (Author, 2013). The SF-MDA of the financial graphs included cohesion analysis of the multimodal finance semiotic resources.

In the next section we present a discussion of the main findings and a conclusion.

\section{DISCUSSION AND CONCLUSION}

The findings of cohesion analysis in finance discourse showed that lexical cohesion formed the largest percentage of use $(<76 \%)$, and in particular reiteration of the same lexical items $(<75.05 \%)$, followed by reference $(<19.79 \%)$. This is normal as topic maintenance involves talking about the same entities (or nouns). As reiteration of the same lexical items was the most frequently occurring cohesive device in the three texts, the most frequently used key words in the three finance texts were calculated. Comparing the findings of the top key words with six management accounting case reports written by non-native speakers of English (BAWE, 2008) reveals an overlap of the top words NPV, project, year, cost and cash.

Conjunctions were primarily used in the three texts to signal enhancement $(<5.25 \%$ of the total cohesive devices) and extension $(<3.72 \%)$ relationships. Extension devices are typically used to provide further related information or to establish counterclaims (e.g. and, also, furthermore, but, however, etc). On the other hand, enhancement devices are used to provide reason (e.g. because, thus, so, etc), to illustrate the manner in which an action takes place (e.g. as, though, although, etc.), and to order the sequential structure of events (e.g. first, second, etc.). Thus whereas these devices expand the utterance by providing circumstantial details such as time, place, manner, cause or condition, elaboration devices expand an utterance by reformulating the 


\section{VOLUME 8}

message to provide focus on the content (e.g. more specifically, in fact, etc). Elaboration devices were minimally used in the three modules $(<.88 \%)$. The findings showed that Additive conjunctions that aim to extend the meaning, in particular 'and', 'also', and 'in addition', had the highest frequency $(<3.34 \%)$, compared to the variation cohesive devices (on the other hand, alternatively, rather, in contrast, or, etc) whose occurrence was below $0.38 \%$. This implies that the participants had difficulties in employing the logico-semantic resources of extension for construing the inter-clausal relations, particularly in the use of variation devices. The lack of these devices may be ascribed to the use of the rhetorical organization in L1 and the Saudi educational system that relies heavily on memorizing. The frequency of reference, though, ranged between $19.79 \%$ and as low as $15.21 \%$ across the three texts. The moderate frequency of reference is ascribed to the fact that the financial tables constitute the major part in accounting discourse.

The findings also showed that the participants underused other lexical and grammatical cohesive devices. These findings support those in other studies (Abusharkh, 2012; Alharbi, 2011; Aljabr, 2011; Alshammari, 2011; Fazelimanie, 2004; Hinkel, 2001; Johns, 1980; Kamal, 1995; Khalil, 1989; Liu \& Braine, 2005; Mohamed-Sayidina, 2010; Mohamed \& Omer, 2000), which found that ESL/EAL students extensively used lexical repetition to convey the interrelationships among ideas, direct the attention of reader/listener, and show the relative foregrounding and backgrounding. For example, Johns (1980) found that lexical cohesion was the most frequently occurring cohesive type in the written business discourse (79\%), while reference was the second most common category (14\%). Similarly, Alshammari's (2011) study showed that lexical repetition constituted $75 \%$ of lexical cohesion uses in the Nano technology students' reports.

Substitution and ellipsis rarely occurred in the three finance texts, as their frequency ranged between $1.15 \%$ and as low as . $41 \%$. The scarce occurrence of these two devices in the participants' texts has also been reported in a number of other studies (Abusharkh, 2012; Al Jarf, 2001; Fazelimanie, 2004; Hessamy \& Hamedi, 2013; Hinkel, 2001; Johns, 1980; Khalil, 1989; Mohamed-Sayidina, 2010). For example, Khalil (1989, p. 363) found that substitution rarely occurred (1.1\%) in ESL students' texts, while ellipsis never occurred. Similarly, AlJarf's (2001) findings showed that EFL college students' difficulties in resolving substitution, reference and ellipsis relationships were due to difficulties in organizing the meaning-making processes through the use of the cohesive devices. The rare occurrence, however, seems to be natural as these ties are more characteristically found in dialogues, where the typical sequence is based on pairs or triads or longer structures that are related by interpersonal meaning. Hessamy and Hamedi (2013), however, ascribe the rare occurrence in their study to the participants' limited knowledge and the influence of their L1, Persian, which permits the use of repetition of words more than English. 
This study adds to our stock of knowledge as it is the first to analyse the use of cohesive devices in a finance course, and in particular in capital budgeting techniques and management reports. A number of pedagogical implications for ESL/EFL students, finance students and educators can be suggested as an outcome of this research study. The SF-MDA of accounting tables and graphs showed that SFL is a powerful resource for analysing meanings inscribed in them. The literacy and numeracy multimodal practices underlying capital budgeting techniques and management reports in finance include understanding the conceptual-procedural confluence, which was revealed through the participants' intuitive interpretations of the graphs. Tutors can devise exercises that help students develop their analytical and critical skills. Whereas analytical skills in capital budgeting techniques refer to students' ability to examine the meaning potential underlying an axis within a statistical graph (intraclausal), critical skills refers to the process of looking for what is not obvious or for different points of view. When students are introduced to the theoretical constructs underlying statistical graphs, their ability to expand the meaning potential in these semiotic resources is enhanced, as the finding has showed that a logico-semantic relation of extension exists between the tables/graphs and the texts accompanying them. Meaning in the multimodal semiotic resources is created not only intrasemiotically but also inter-semiotically through the interaction of the graph and the accompanying linguistic text (O'Halloran, 2008).

As conjunctive devices of elaboration were minimally used $(.88 \%)$ by the students, tutors can help students understand how propositions are expanded through elaboration. ESL/EFL learners can be introduced into the ways of expanding the meaning-making potential through the introduction of these devices in business ESP/EAP courses. Practising the conjunctive devices of expansion promote students' repertoire of syntactic alternatives. As variation and appositive conjunctive devices were rarely used $(<.37 \%$ and $.14 \%$ respectively), tutors can help students to recognise the various subcomponents of expansion that combine with tactic relations to link one clause to another. Similarly, Business ESP/EAP learners can be introduced into the uses of substitution and ellipsis, including the use of ellipsis as a means to avoid redundancy in accounting discourse. The taxonomic classifications of synonyms, hyponyms, hypernyms, meronyms, and antonyms rarely occurred in three texts. As the field of business discourse is managed through lexical strings and the relationships that exist between them, tutors can introduce students into lexical strings through the use of concordances. They can implement exercises requiring students to extract these devices from business texts written by native speakers, and to expand the related meaning making potential. 


\section{VOLUME 8}

Finally, it should be noted that the findings were not based on a representative sample of the discipline's academia. In other words, since the generalizations we presented in this research study reflect only a sub-set of the full range of the literacy and numeracy practices, they are of the moderatum (Williams, 2000) kind since they are inevitable; however, they are limited as they represent an instances of a broader recognisable set of features.

\section{REFERENCES}

Abusharkh, B. (2012). Cohesion and coherence in the essay writing of Palestinian college students. Unpublished MA thesis, Hebron University, Hebron, Palestine. Retrieved from http://elearning.hebron.edu

Al Jarf, R. S. (2001). Processing of cohesive ties by EFL Arab college students. Foreign Language Annals, 34(2), 141-151.

Alharbi, A. (2011). An investigation into the English writing of two culturally and linguistically diverse student groups in the Pre-Enrolment English Program (PEP) at Adelaide University. Unpublished MA thesis, University of Adelaide, Adelaide, Australia.

AlHuthali, M. (2007). The construction of mechanical engineering literacies: autonomous or social practices? Unpublished MA dissertation, University of Adelaide, Australia.

Aljabr, F. (2011). An analysis of cohesion and thematic development in university assignments written by undergraduate English major students in one Saudi univesrity. Unpublished MA thesis, University of Adelaide, Adelaide, Australia.

Alshammari, B. (2011). A cohesion analysis of scientific papers written by Saudi students in an Australian University. Unpublished MA thesis, University of Adelaide, Adelaide, Australia.

Author. (2013).

Author. (2014).

Author. (2011).

Bargiela-Chiappini, F. (2009). The handbook of business discourse. Edinburgh: Edinburgh University Press.

BAWE. (2008). British academic written English corpus, from http://www.ota.ox.ac.uk

Brigham, E., \& Houston, J. (2009). Fundamentals of Financial Management (12th ed.). South-Western: Cencage Learning.

Cazden, C., Cope, B., Fairclough, N., Gee, J., Kalantzis, M., Kress, G., et al. (1996). A pedagogy of multiliteracies: Designing social futures. Harvard Educational Review, 66(1), 60-92.

Chan, K., Shum, C., \& Wright, D. (1997). Class attendance and student performance in principles of finance. Financial Practice and Education, 7(2), 58-65.

Conaway, R. N., \& Wardrope, W. J. (2010). Do their words really matter? Thematic analysis of US and Latin American CEO letters. Journal of Business Communication, 47(2), 141-168. doi: http://dx.doi.org/10.1177/0021943610364523

Cope, B., \& Kalantzis, M. (2000). Multiliteracies: Literacy learning and the design of social futures. New York: Routledge. 
Cope, B., \& Kalantzis, M. (2013). "Multiliteracies": New literacies, new learning. In M. Hawkins (Ed.), Framing languages and literacies: Socially situated views and perspectives (pp. 105-135). UK: Routledge.

Crawford Camiciottoli, B. (2010). Discourse connectives in genres of financial disclosure: Earnings presentations vs. earnings releases. Journal of Pragmatics, 42(3), 650-663. doi: http://dx.doi.org/10.1016/j.pragma.2009.07.007

Davidson, R. (2005). Analysis of the complexity of writing used in accounting textbooks over the past 100 years. Accounting Education, 14(1), 53-74. doi: http://dx.doi.org/10.1080/09639280410001695241

de Oliveira, L., \& Cheng, D. (2011). Language and the multisemiotic nature of mathematics. Reading Matrix: An International Online Journal, 11(3), 255-268.

Drury, H., O' Carroll, P., \& Langrish, T. (2006). Online approach to teaching report writing in chemical engineering: implementation and evaluation. International Journal Engineering Education, 22(4), 858-867.

Eggins, S. (2007). An Introduction to Systemic Functional Linguistics (2nd. ed.). London \& New York: Continuum.

Fazelimanie, A. (2004). A linguistic analysis of some ESP texts used in Iranian universities with special focus on cohesion in texts of business and commerce. Unpublished Ph.D. thesis University of Adelaide Retrieved from http://digital.library.adelaide.edu.au

Garzone, G. (2009). Multimodal analysis. In F. Bargiela-Chiappini (Ed.), The handbook of business discourse (pp. 155-165). Edinburgh: Edinburgh University Press.

Guo, L. (2004). Multimodality in a biology textbook. In K. O'Halloran (Ed.), Multimodal discourse analysis: systemic-functional perspectives (pp. 196-219). London/ New York: Continuum.

Halliday, M. (1985). An introduction to functional grammar. London: Edward Arnold.

Halliday, M., \& Hasan, R. (1976). Cohesion in English. London: Longman

Halliday, M., \& Hasan, R. (1985). Language, context, and text: Aspects of language in a social-semiotic perspective. Victoria: Deakin University Press.

Halliday, M., \& Matthiessen, C. (2004). An introduction to functional grammar (3rd revised edition of Halliday's Introduction to Functional Grammar ed.). London: Hodder-Arnold.

Hessamy, G., \& Hamedi, S. (2013). A comparison of the use of cohesive devices in EFL Learners' performance on independent vs. integrated writing tasks. Study in English Language Teaching, 1(1), p121.

Hinkel, E. (2001). Matters of cohesion in L2 academic texts. Applied Language Learning, 12(2), 111-132.

Hyland, K. (1998). Exploring corporate rhetoric: metadiscourse in the CEO's letter. Journal of Business Communication, 35(2), 224-245.

Johns, A. M. (1980). Cohesion in written business discourse: Some contrasts. The ESP Journal, 1(1), 35-43.

Jones, J. (2006). Multiliteracies for academic purposes: A metafunctional exploration of intersemiosis and multimodality in university textbook and computer-based learning resources in science. Unpublished Doctor of EdD thesis, University of Sydney. Retrieved from http://hdl.handle.net/2123/2259 


\section{VOLUME 8}

Kalantzis, M., \& Cope, B. (2012). Literacies. Melobourne: Cambridge University Press.

Kamal, E. (1995). The rendition of English cohesive devices into Arabic: A study of translated texts. Unpublished MA dissertation, King Saudi University, Saudi Arabia.

Khalil, A. (1989). A study of cohesion and coherence in Arab EFL college students' writing. System, 17(3), 359-371.

Kress, G., \& van Leeuwen, T. (1996). Reading images: The grammar of visual design. London: Routledge.

Lea, M., \& Street, B. (2006). The "academic literacies" model: Theory and applications. Theory into Practice, 45(4), 368-377.

Liu, M., \& Braine, G. (2005). Cohesive features in argumentative writing produced by Chinese undergraduates. System, 33(4), 623-636.

Martinec, R., \& Salway, A. (2005). A system for image-text relations in new (and old) media. Visual communication, 4(3), 337-371.

Mohamed-Sayidina, A. (2010). Transfer of L1 cohesive devices and transition words into L2 academic texts: The case of Arab students. RELC Journal, 41(3), 253266. doi: http://dx.doi.org/10.1177/0033688210380569

Mohamed, A., \& Omer, M. (2000). Texture and culture: Cohesion as a marker of rhetorical organisation in Arabic and English narrative texts. RELC Journal, 31(2), 45-75. doi: http://dx.doi.org/10.1177/003368820003100203

Monteiro, C., \& Ainley, J. (2006). Student teachers interpreting media graphs. Paper presented at the Proceedings of the Seventh International Conference on Teaching Statistics.

Nga, C. T. H. (2012). Analysis of cohesive devices in the ESP textbook on accounting at university of labor and social affairs. Unpublished MA thesis, University of Languages and International Studies, Vietnam.

O'Halloran, K. (1996). The discourses of secondary school mathematics. Unpublished Ph.D. thesis, Murdoch University, Western Australia. Retrieved from http://researchrepository.murdoch.edu.au

O'Halloran, K. (1999). Towards a systemic functional analysis of multisemiotic mathematics texts. Semiotica, 124(1/2), 1-29.

O'Halloran, K. (2000). Classroom discourse in mathematics: A multisemiotic analysis. Linguistics and Education, 10(3), 359-388.

O'Halloran, K. (2004). On the effectiveness of mathematics. In E. Ventola, C. Charles \& M. Kaltenbacher (Eds.), Perspectives on multimodality (pp. 91-118). Amsterdam: John Benjamins Publishing Company.

O'Halloran, K. (2005). Mathematical discourse: Language, symbolism and visual images. London: Continuum.

O'Halloran, K. (2008). Mathematical and scientific forms of knowledge: A systemic functional multimodal grammatical approach. In F. Christie \& J. R. Martin (Eds.), Language, knowledge and pedagogy: Functional linguistic and sociological perspectives (pp. 205-236). London: Continuum.

O'Toole, M. (1994). The language of displayed art. London: Leicester University Press.

O'Halloran, K. (2009). Systemic functional multimodal discourse analysis (SF-MDA) approach to mathematics, grammar and literacy. In A. McCabe, M. O'Donnell \& 
R. Whittaker (Eds.), Advances in language and education (pp. 77-102). London $\&$ New York: Continuum. (Reprinted from: 2007).

Okawa, T. (2008). Academic literacies in the Discipline of Nursing: Grammar as a resource for producing texts. Unpublished MA dissertation, University of Adelaide, Adelaide.

Pauwels, L. (2012). A multimodal framework for analyzing websites as cultural expressions. Journal of Computer-Mediated Communication, 17(3), 247-265. doi: http://dx.doi.org/10.1111/j.1083-6101.2012.01572.x

Perren, L., \& Grant, P. (2000). The evolution of management accounting routines in small businesses: A social construction perspective. Management Accounting Research, 11(4), 391-411. doi: http://dx.doi.org/10.1006/mare.2000.0141

Prince, R., \& Archer, A. (2008). A new literacies approach to academic numeracy practices in higher education. Literacy and Numeracy Studies, 16(1), 63-76.

Royce, T. (2002). Multimodality in the TESOL classroom: Exploring visual-verbal synergy. TESOL Quarterly 36(2), 191-205. doi: http://dx.doi.org/10.2307/3588330

Rutherford, B. A. (2005). Genre analysis of corporate annual report narratives: A corpus linguistic-based approach. International Journal of Business Communication, 42(4), 349-378. doi: http://dx.doi.org/10.1177/0021943605279244

Sen, S., Joyce, P., Farrell, K., \& Toutant, J. (1997). Performance in principles of finance courses by students with different specializations. Financial Practice and Education, 7(2), 66-73.

Textalyser. (2004). Analysis Tool, Version 1.05, 2011, from http://textalyser.net/

Thomas, J. (1997). Discourse in the marketplace: The making of meaning in annual reports. Journal of Business Communication, 34(1), 47-66.

Wake, B. (2006). Dialogic learning in tutorial talk: A case study of semiotic mediation as a learning resource for second language international students. Unpublished Ph.D. thesis, University of Adelaide, Adelaide.

Williams, M. (2000). Interpretivism and generalisation. Sociology, 34(2), 209-224. 